\title{
Penerapan Digital Marketing Pada Kedai Cimanuk Berbasis Website
}

\section{Application of Digital Marketing at Kedai Cimanuk based on website}

\author{
Ninik Haryani ${ }^{1}$, Listiarini Edy Sudiati ${ }^{2}$, Ngasri $^{3}$ \\ ${ }^{123}$ STMIK AKI Pati \\ 1․ㅡㄹikwinong@gmail.com, ${ }^{2} \underline{\text { listiarini@gmail.com, }}{ }^{3}$ ngasrihadi@gmail.com
}

\begin{abstract}
Abstrak
Digital marketing merupakan salah satu media yang saat ini sedang banyak diminati oleh masyarakat serta sebagai pendukung dalam kegiatan sehari hari. Secara perlahan lahan banyak masyarakat yang mulai meninggalkan cara marketing konvensional dan beralih pada digital marketing. Kedai Cimanuk harus memperhatikan sisi strategi pemasaran untuk mendorong dan membangun konsumen untuk melakukan keputusan pembelian hingga memenuhi kebutuhan dan keinginannya. Sistem yang dibangun merupakan sistem digital marketing, dengan sistem ini bisa meningkatkan jangkauan pemasaran menjadi lebih luas. Dengan adanya sistem digital marketing maka diharapkan Kedai Cimanuk tidak mengalami kesulitan dalam mempromosikan, menginformasikan, menperbaharui berita terbaru serta melayani pelanggan dan dapat membantu pelanggan dalam melakukan proses pemesanan dengan cepat dan memudahkan pelanggan untuk mendapatkan informasi yang lebih lengkap.
\end{abstract}

\section{Kata kunci : Digital Marketing, Social Media, Sistem Informasi, Website}

\begin{abstract}
Digital marketing is one of the media that is currently in great demand by the community as well as a support in daily activities. Slowly, many people are starting to leave conventional marketing methods and switch to digital marketing. Cimanuk shops must pay attention to the marketing strategy side to encourage and build consumers to make purchasing decisions to meet their needs and wants. The system built is a digital marketing system, with this system it can increase marketing reach to a wider range. With the digital marketing system, it is hoped that the Cimanuk shop will have no difficulty in promoting, informing, updating the latest news and serving customers and can help customers make the order process quickly and make it easier for customers to get more complete information.
\end{abstract}

Keywords: Digital Marketing, Social Media, Information Systems, Website

\section{PENDAHULUAN}

Pada saat ini berkembangnya teknologi dan komunikasi menjadi sangat pesat, hampir semua orang mengenal handphone atau telefon genggam, sebuah benda yang diciptakan sebagai media komunikasi yang cepat, mudah dan juga praktis. Pada awalnya benda tersebut merupakan benda mewah, yang tidak semua orang dapat miliki tetapi sekarang semua orang sudah pasti mempunyai handphone sebagai media tukar menukar informasi antara satu individu dengan individu lain nya [5].

Pemasaran digital (Digital Marketing) merupakan salah satu media yang saat ini diminati 
oleh masyarakat serta dukungan dalam kegiatan sehari-hari mereka. Dengan perlahan-lahan banyak orang mulai meninggalkan cara pemasaran konvensional dan beralih ke pemasaran digital[5]. Digital marketing sendiri memiliki pasar makna atau mempromosikan merek atau produk dalam dunia digital atau internet [2].

Kedai Cimanuk adalah salah satu toko baru yang bergerak dalam bidang kuliner untuk memenuhi kebutuhan dan keinginan konsumen yang semakin dinamis. Kedai Cimanuk hadir untuk memperkenalkan berbagai minuman dan makanan yang sehat. Kedai Cimanuk harus memperhatikan strategi pemasaran untuk mendorong dan membangun konsumen untuk membuat keputusan pembelian untuk memenuhi kebutuhan dan keinginan pelanggan. Pada saat ini masih terdapat masalah yang dihadapi oleh Kedai Cimanuk yaitu hasil dari penjualan yang diperoleh penjualan online tidak selalu sesuai dengan harapan dan pihak Kedai Cimanuk masih kesulitan dalam menganalisa jumlah pengunjung atau pelanggan.

Melihat situasi dan kondisi di atas, sehingga peneliti tertarik untuk membahas konsep "Penerapan Digital Marketing Pada Kedai Cimanuk Berbasis Website". Dengan sistem tersebut diharapkan dapat membantu Kedai Cimanuk dalam memasarkan produk untuk meningkatkan penjualan dan memudahkan pelanggan memperoleh informasi yang akurat.

\section{DASAR TEORI /MATERIAL DAN METODOLOGI/PERANCANGAN}

\subsection{Pengertian Sistem Informasi}

Sistem informasi adalah komponen-komponen yang saling berkaitan yang bekerja bersamasama untuk mengumpulkan, mengolah, menyimpan, dan menampilkan informasi untuk mendukung pengambilan keputusan, koordinasi, pengaturan, analisa, dan visualisasi pada sebuah organisasi (Teori 2010). Pendapat O'Brien bahwa komponen suatu sistem informasi terbagi atas beberapa hal, yaitu:

1. Sumber daya data (sebagai data dan pengetahuan).

2. Sumber daya manusia (sebagai pemakai akhir dan ahli SI).

3. Sumber daya software (sebagai program dan prosedur).

4. Sumber daya hardware (mesin dan media).

5. Sumber daya jaringan (sebagai media komunikasi dan dukungan jaringan).

\subsection{Digital Marketing}

Digital Marketing Adalah praktek marketing yang menggunakan saluran distribusi digital untuk mencapai konsumen dengan cara yang relevan, personal dan cost-effective. Aktivitas pemasaran dilakukan secara intensif menggunakan media komputer, baik mulai dari penawaran produk, pembayaran dan pengiriman. Dalam konteks marketing, kondisi krisis global membuat banyak organisasi mulai mencari metode penghematan [3]. Tidak menjadi rahasia umum bahwa biaya terbesar organisasi berasal dari biaya marketing dan tenaga kerja. Oleh sebab itu, organisasi bisnis harus pandai melihat peluang melakukan aktivitas marketing yang efektif di era digital dengan biaya yang murah dan efektif [1][5].

\subsection{Pemasaran Media Sosial}

Pemasaran media sosial atau sering disebut social media marketing[1] adalah bentuk pemasaran langsung atau tidak langsung yang digunakan untuk membangun kesadaran, pengakuan, ingat, dan tindakan untuk merek, bisnis, produk, orang, atau badan lain dan dilakukan dengan menggunakan alat-alat dari web sosial, seperti sebagai berbagai blogging, mikrobloging, 
jejaring sosial, bookmark sosial, dan konten [2][3].

\subsection{UML ( Unified Modelling Language )}

Menurut Nugroho (2015), UML merupakan bahasa untuk visualisasi, spesifikasi, konstruksi, serta dokumentasi. UML sebagai suatu cara untuk mengkomunikasikan idenya kepada para pemrogram serta calon pengguna sistem / perangkat lunak. Dengan adanya bahasa yang bersifat standar, komunikasi perancang dengan pemrogram (komunikasi antar anggota kelompok pengembang) serta calon pengguna diharapkan menjadi mulus [6].

\subsection{Basis Data}

Database adalah kumpulan data tentang suatu benda atau kejadian yang saling berhubungan satu sama lain (berelasi). Sistem basis data adalah suatu menyusun dan mengelola record-record menggunakan komputer untuk penyimpanan atau merekam atau serta memelihara data operasional lengkap sebuah operasional atau perusahaan sehingga mampu menyediakan informasi yang optimal yang diperlukan pemakai untuk proses pengambilan keputusan [6].

\subsection{Website}

Sistem WWW (World Wide Web) biasa disingkat dengan istilah web, adalah suatu ruang informasi yang dipakai oleh pengenal global yang disebut URI (Uniform Resource Identifier) untuk mengindentifikasi sumber daya yang berguna. Informasi yang dihasilkan web dapat berupa teks, gambar, audio visual, model grafis, film dan lain-lain. Web menggunakan hypertext link yang memudahkan pencarian informasi dalam berbagai bentuk[6].

\subsection{Metodologi Penelitian}

Tujuan dari penelitian ini adalah untuk menghasilkan sistem informasi digital marketing pada Kedai Cimanuk yang membantu proses penjualan, pembelian, ketepatan dalam inventori atau pemeriksaan persediaan, laporan penjualan dan analisa pengunjung. Untuk menyusun laporan yang baik dan benar diperlukan data-data yang akurat. Metode yang digunakan adalah Metode kualitatif yang merupakan berusaha memahami dan menafsirkan makna suatu peristiwa interaksi tingkah laku manusia dalam situasi tertentu menurut perspektif peneliti sendiri[4]. Penelitian menggunakan penelitian kualitatif untuk memahami subjek studi secara menyeluruh (Gunawan, 2013). Metode penelitian yang digunakan untuk menyusun penelitian sebagai berikut :

\subsubsection{Pengumpulan Data}

Pengumpulan data untuk menyusun laporan ini menggunakan beberapa cara diantaranya adalah:

1. Wawancara (interview)

Teknik pengumpulan data dengan cara memberikan pertanyaan langsung dari pewawancara kepada responden atau narasumber, dan jawaban responden dicatat atau direkam. Dalam hal ini penyusun melakukan wawancara kepada pemilik Kedai Cimanuk, Saudara Jeremia Mahendra Pratama.

2. Studi Dokumen

Pengumpulan data berdasar literatur dari berbagai buku, majalah, surat kabar, atau sumber- 
sumber lain yang berhubungan dengan objek penelitian serta catatan .

3. Observasi

Mengamati dan mempelajari sistem yang ada beserta segala sesuatu yang berkaitan dengan masalah yang diteliti, observasi sebagai teknik pengumpulan data mempunyai ciri yang spesifik bila dibandingkan dengan teknik yang lain. Metode observasi dilakukan dengan mengumpulkan data langsung dari keadaan dari Kedai Cimanuk

\subsubsection{Analisa}

Digunakan untuk menyelidiki secara terperinci semua aktifitas transaksi dan relasimasalah yang terjadi. Untuk mendapatkan bahan sebagai komponen utama program yang akan di buat.

\subsubsection{Perancangan Desain Sistem}

Diagram konteks memberikan gambaran umum mengenai interaksi yang terjadi antara user, sistem,dan admin. Dimana tugas seorang admin adalah menginputkan data pada sistem dan sistem yang akan menghasilkan laporan-laporan, sedangkan user dapat mendapatkan informasi tentang harga dan ketersediaan.

\section{PEMBAHASAN}

\subsection{Analisa PIECES}

Dengan ditemukan kondisi dan permasalahan yang ada, diperlukan sistem penyampaian informasi yang lebih baik. Salah satu cara untuk mengatasi permasalahan yang ada saat ini, maka Kedai Cimanuk perlu melakukan identifikasi masalah dengan menggunakan kerangka PIECES yaitu analisis terhadap kinerja, informasi, ekonomi, keamanan, efisiensi, dan pelayanan. Dengan analisa ini dapat diketahui sistem yang baru yaitu sistem digital marketing, memiliki banyak keunggulan daripada sistem yang masih berjalan saat ini.

Untuk mengukur dan menentukan ketepatan dalam menganalisis masalah yang terjadi maka, penulis memilih analisa pieces sebagai tolak ukur untuk merancang sistem yang baru, Metode ini menggunakan 6 variable yaitu :

1. Performance (Kinerja)

Pengaksesan bisa dilakukan di mana saja

2. Inforkeation (Informasi)

Saat ada info atau berita terbaru, pengguna bisa langsung mengetahuinya melalui notifikasi.

3. Economics (Ekonomi)

Memanfaatkan koneksi data dari provider.

4. Control (Pengendalian)

Aplikasi lebih mudah pengoperasiannya dan user friendly dengan interaksi langsung lewat teknologi touch screen.

5. Efficiency (Efisiensi)

Penyampain segala informasi jauh lebih efisiensi.

6. Service (Layanan)

Selalu terhubung dengan server database, jika terjadi masalah atau ada pembaharuan dari pengembang langsung menerima pemberitahuan lewat notifikasi, tanpa harus menunggu user membuka aplikasi. 


\subsection{Perancangan Sistem}

Setelah tahap analisis sistem dilakukan maka berikutnya adalah merancang desain sistem. Dengan merancang model tersebut sehingga mendapatkan hasil sesuai yang diharapkan.

Perancangan sistem digital marketing pada Kedai Cimanuk berbasis website menggunakan sistem berorientasi objek, dengan bahasa pemrograman UML.

\subsubsection{Use Case}

Use Case diagram adalah penggambaran fungsi tertentu dalam suatu sistem berupa komponen, kejadian atau kelas

1. Use Case diagram Admin

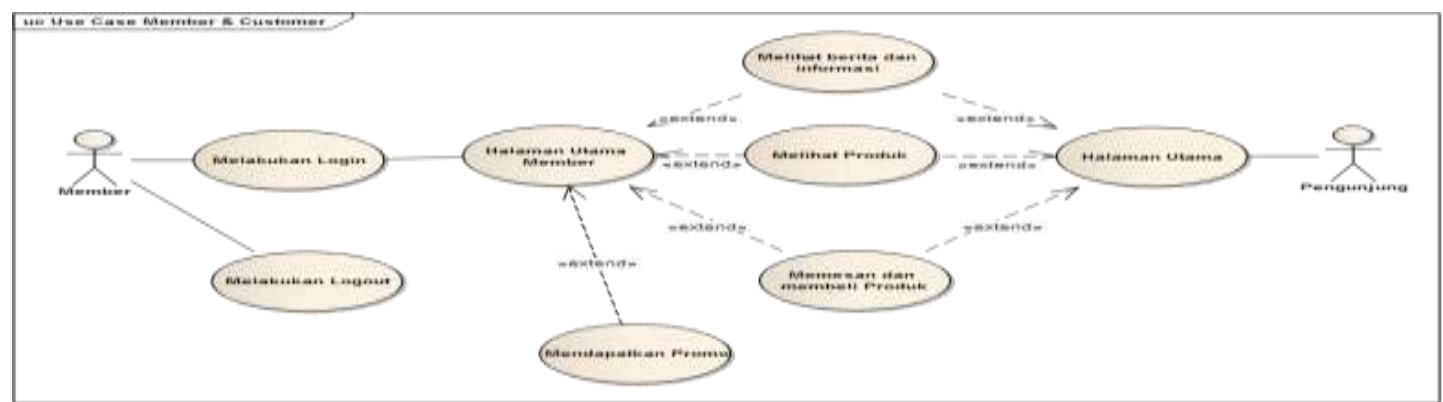

Gambar 1. Use Case diagram admin

Keterangan :

Pada diagram Use case diatas, yang bertindak sebagai aktor adalah admin memiliki kewenangan untuk menambah, mengubah atau menghapus data di dalam database yang berkaitan dengan website.

2. Use case Member dan Pengunjung

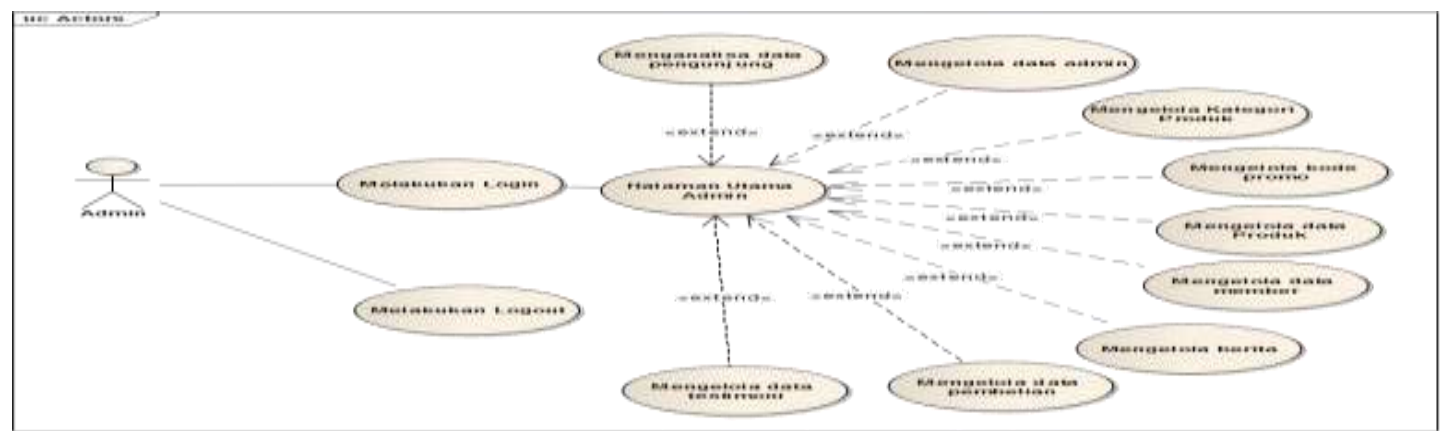

Gambar 2. Use case Member dan Pengunjung

Keterangan :

Member melakukan login ke dalam sistem dan berhak menerima promo dari toko. Member tidak memiliki hak akses untuk mengubah atau menambah isi dari sistem.

\subsection{Sequence Diagram}

Sequence diagram menjelaskan interaksi objek yang disusun berdasarkan urutan waktu. Secara mudahnya sequence diagram adalah gambaran tahap demi tahap, termasuk kronologi (urutan) perubahan secara logis yang seharusnya dilakukan untuk menghasilkan sesuatu sesuai dengan use case diagram. 
1. Sequence diagram admin login

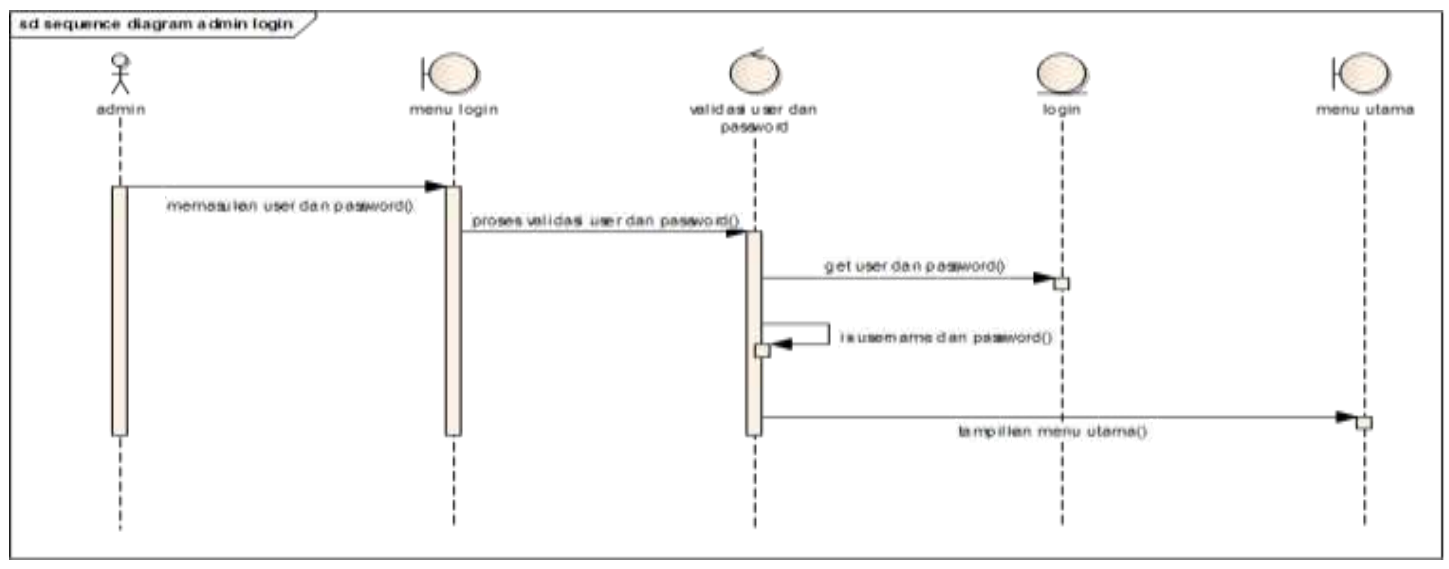

Gambar 3. Sequence diagram admin login

Keterangan :

Admin masuk halaman awal website untuk melakukan kegiatan login ke sistem. Dimana admin yang bertugas mengisi username dan password, kemudian sistem memvalidasi, jika valid sistem akan menampilkan konfirmasi berhasil kepada amin, jika tidak valid maka sistem akan menampilkan pesan kesalahan/error, dan kembali pada halaman awal form login.

2. Sequence diagram member login

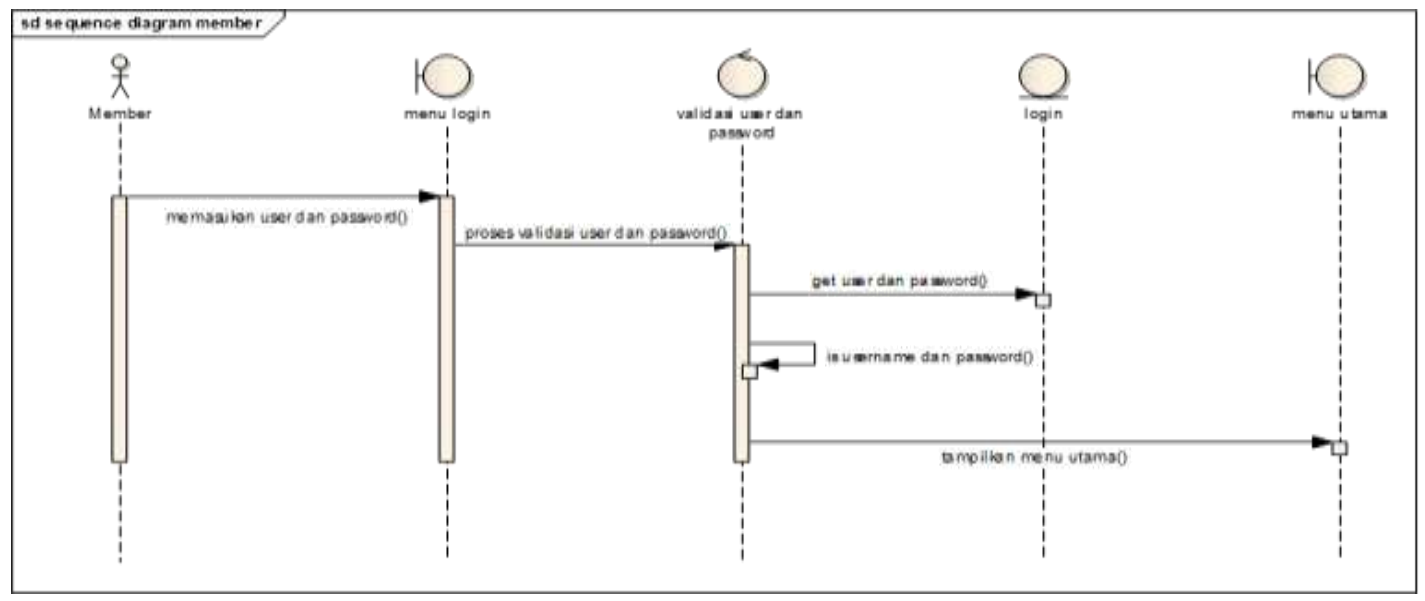

Gambar 4. Sequence diagram member login

Keterangan :

Member masuk halaman awal website untuk melakukan kegiatan login ke sistem. Mengisi username dan password, kemudian sistem memvalidasi, jika valid sistem akan menampilkan konfirmasi berhasil kepada member, jika tidak valid maka sistem akan menampilkan pesan kesalahan/error, dan kembali pada halaman awal form login.

\subsection{Hasil Tampilan}

1. Tampilan Halaman Utama

Halaman utama adalah tampilan awal dari kedai cimanuk yang berisi beberapa menu untuk digunakan. 


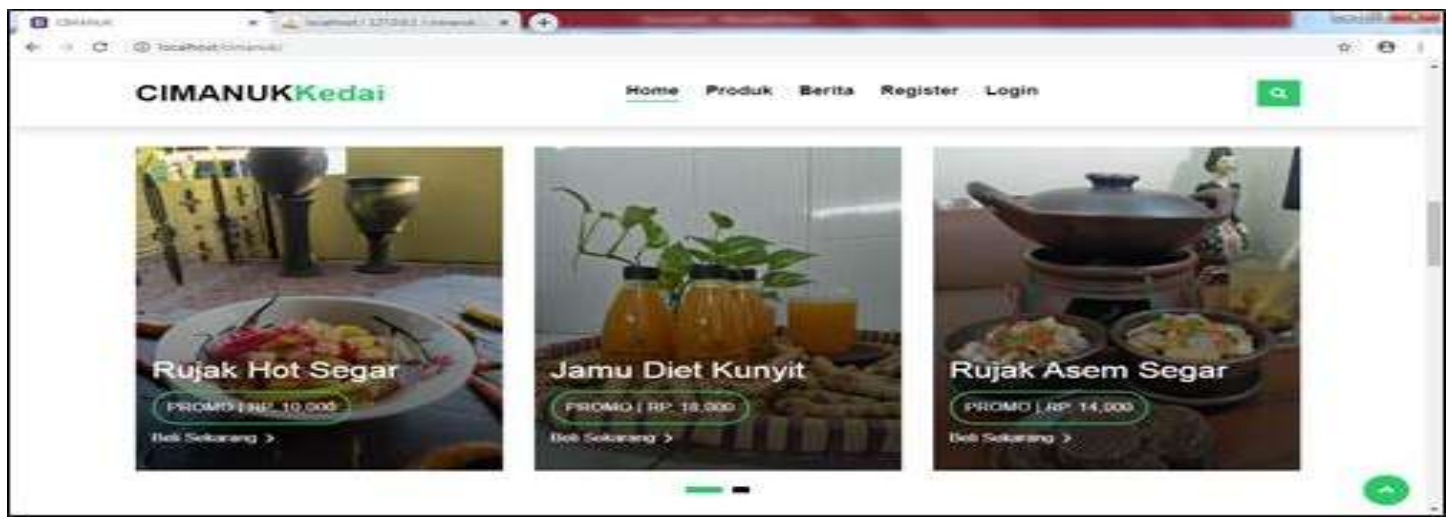

Gambar 7.Tampilan Halaman Utama

2. Halaman Utama Admin

Tampilan halaman utama admin merupakan tampilan awal saat membuka website. Terdapat beberapa menu diantaranya menu kelola data member, pembelian, berita dan terstimoni

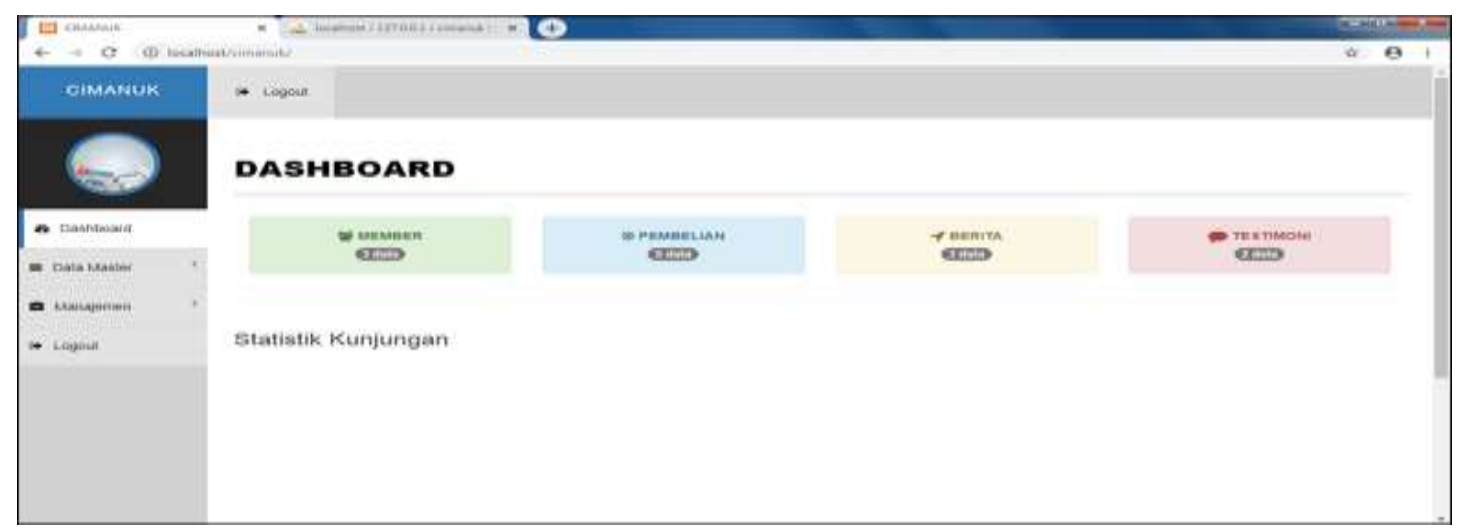

3. Halaman Utama Admin

Gambar 8. Halaman Utama Admin

Tampilan halaman utama admin merupakan tampilan awal saat membuka website. Terdapat beberapa menu diantaranya menu kelola data member, pembelian, berita dan terstimoni

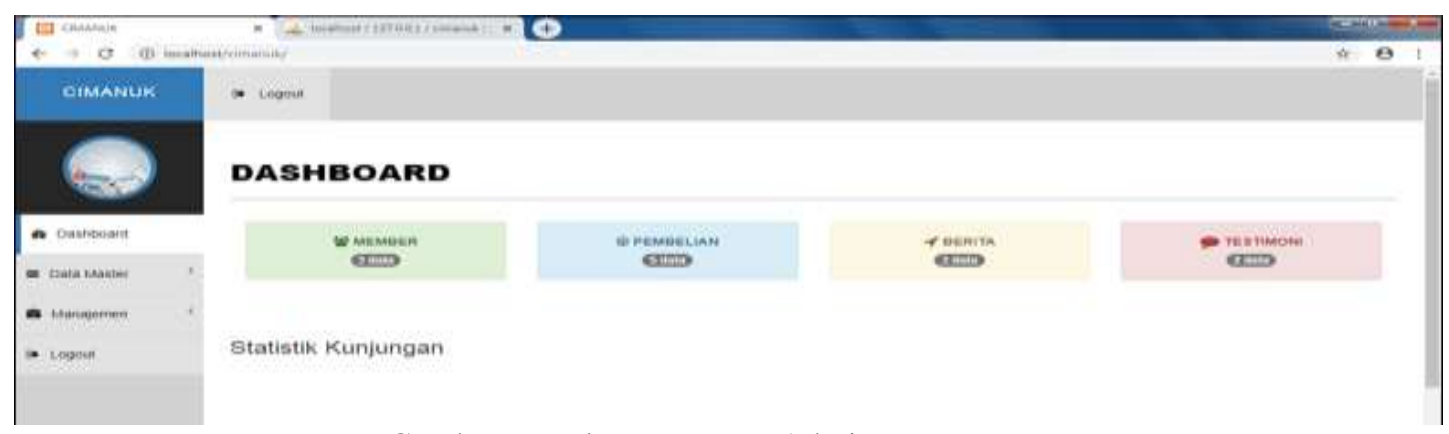

Gambar 9. Halaman Utama Admin

4. Tampilan Menu Kelola Data

Tampilan menu mengelola data admin merupakan tampilan yang digunakan admin untuk 
memasukan data admin diantaranya nama, jenis kelamin, telpon dan lain-lain.

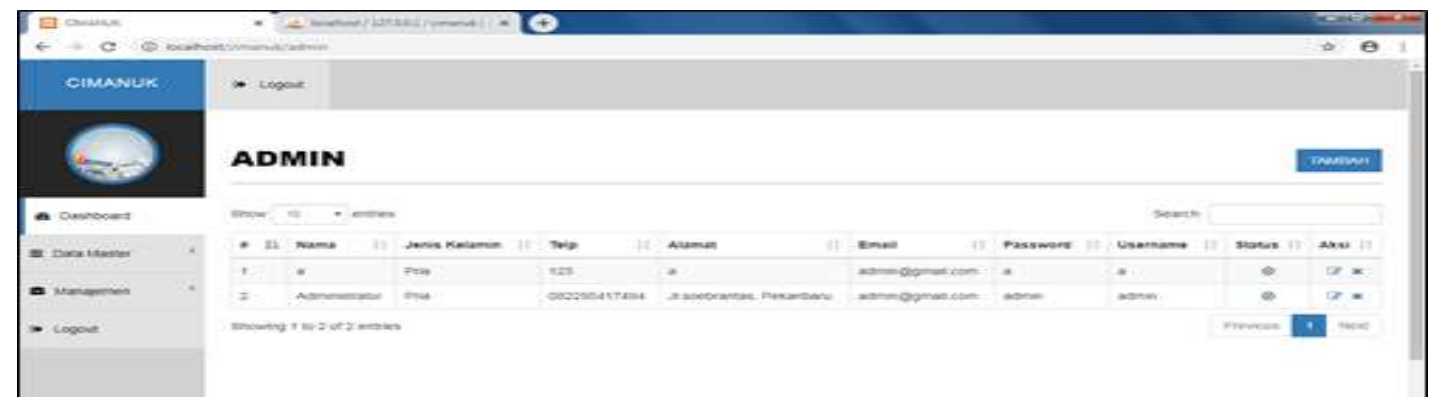

Gambar 10. Tampilan Menu Kelola Data

\subsection{Sistem Keamanan}

Sistem keamanan yang meliputi keamanan komputer data dan jaringan sangatlah penting karena ini juga berkaitan kepada kegiatan yang dilakukan secara online. Sehingga data yang dimiliki terjamin kerahasiaanya dan keamananya. Sistem keamanan yang di menggunaan antivirus Avira dan Smadav serta Penerapan pasword log in

\section{KESIMPULAN}

Berdasarkan hasil dan pembahasan yang sudah diuraikan, maka kesimpulan yang dapat diambil adalah sebagai berikut :

1. Kedai Cimanuk selama ini marketing prosesnya masih belum menggunakan sistem yang terintegrasi atau memanfaatkan digital marketing yang meliputi media sosial dan marketplace.

2. Belum adanya sistem untuk mengelola proses penjualan dan belum adanya sistem yang terintegrasi dengan media sosial.

3. Sistem yang dibangun merupakan sistem digital marketing, dengan sistem ini bisa meningkatkan jangkauan pemasaran menjadi lebih luas.

4. Dengan adanya sistem digital marketing maka diharapkan Kedai Cimanuk tidak mengalami kesulitan dalam mempromosikan, menginformasikan, mengupdate berita terbaru serta melayani pelanggan dan dapat membantu pelanggan dalam melakukan proses pemesanan dengan cepat dan memudahkan pelanggan untuk mendapatkan informasi yang lebih lengkap.

5. Sistem yang dibangun diharapkan bisa menjadi solusi terhadap permasalahan yang dihadapi oleh Kedai Cimanuk seperti dalam transaksi penjualan produk bisa lebih baik, cepat dan efektif.

\section{DAFTAR PUSTAKA}

[1] Diamond, Stephanie. 2015. The Visual Marketing Revolution. Jakarta : Serambi Ilmu Semesta

[2] M Nisrina. 2015. Bisnis Online : Manfaat Media Sosial dalam Meraup Uang. Yogyakarta : Kobis.

[3] Shinta, Agustina. 2011. Manajemen Pemasaran. Malang: UB Press. Timur.

[4] Sugiyono, P.D.2015. Metode Penelitian dan Pengembangan. Bandung : ALFABETA

[5] Desti Putri Lestari. 2014. Analisi Strategi Internet Marketing Butik Online Di Surabaya Melalui Instagram

[6] Nore, Victor Nocolas. 2013. Perancangan Sistem Informasi Penjualan dan Pemasaran Produk Berbasis Web. Bandung: Program Studi Sistem Informasi Fakultas Teknik Universitas Widyatama. 
JELC

Jurnal Elektro Luceat [Oktober $\rceil[2020]$ 